Johanna Pentikäinen

\title{
Tutkimustarinat - opinnäytteen kirjoittamisen kaaria, kumppaneita ja kultaruukkuja
}

Suomalainen kirjoittamista koskeva kansanviisaus ja muu selkänahkaoppi korostaa sitä, että onnistuneet tekstit syntyvät uutteran työn ja kärsivällisyyden seurauksena. "Hiljaa hyvää tulee". "Askel kerrallaan". "Tyvestä puuhun noustaan". "Lopussa kiitos seisoo". "95\% perspiraatiota ja sitten $5 \%$ inspiraatiota, jos on tullakseen". Saman idean akateeminen formulointi löytyy prosessikirjoittamisen opeista. Prosessikirjoittaminen, tuo angloamerikkalaisessa maailmassa 1980-luvulla kehitetty ja Suomeen sittemmin napakasti juurtunut kirjoittamisen opettamisen suuntaus, jäsensi tekstin valmistamisen työvaiheiden sarjaksi. Yksittäisin askelin edetään alun aiheen hahmottamisesta ja ideoinnista loppuun, tekstin hiomiseen julkaisukuntoon. Työvaiheita voi olla monta, esittäjistä riippuen yleensä 5-10, ja niiden sisällys on kutakuinkin tämä:

tekstin suunnittelu

aineiston kokoaminen

tekstin luonnostelu

tekstin kirjoittaminen

tekstin muokkaaminen ja julkistaminen

(ks. esim. Linnakylä et.al. 1992).

Prosessikirjoittaminen tarjoaa välineen käytännön työskentelyn ja siinä tarvittavien tiedonhankinta- ja muiden vaiheiden valmisteluun, mutta itse kirjoittamisesta se kertoo vain vähän. Malli onkin syntynyt kognitiivisen psykologian tutkimusten pohjalta; ei se kerro itse teksteistä tai luovan työn keskeisestä edellytyksestä, näkemyksestä tekstin tavoitteesta (Ivanic 2004, 231).

Malli ei auta vastaamaan seuraaviin kysymyksiin: Miksi kirjoitat? Mitä annettavaa sinulla on? Mitä voit oppia tämän tekstin kirjoittamisen aikana? Kuka on oletettu lukijasi ja miksi hän lukisi tekstisi? Miten haluat vaikuttaa oletettuun lukijaasi? Kuitenkin nämä kysymykset mittaavat sitä, onko tekstin kirjoittaminen ylipäätään mielekästä, vai onko se kirjoittajalleen ja mahdolliselle lukijallekin vain kenties tyylipuhdasta, mutta kuitenkin mekaanista suorittamista.

Niin prosessikirjoittamisen mallit kuin muutkin mallit ovat luonnollisesti syntyneet helpottamaan kirjoittajan työtä, ja sellaisina niillä on oma tärkeä merkityksensä työsuorituksen jäsentämisessä. Mutta vaarana on, että samat mallit alkavat vaikuttaa siihen, miten itse kohde, kirjoittaminen, ymmärretään. Silloin mallit ovat karanneet karsinoistaan. Työvälineistä on tullut rouvia ja herroja, vaikka alun perin niiden tuli vain helpottaa herrasväen elämää. 
Lastenlaulussa Sateenkaaren päässä kerrotaan sateenkaaren päässä odottavasta kultaruukusta ja houkutellaan kulkijaa lähtemään matkalle etsimään aarretta. Viimeisessä säkeistössä todetaan lohdullisesti, ikään kuin aavistaen, etteivät kaikki suunnitelmat ja toiveet aina ainakaan sellaisinaan toteudu, että jos kulkija matkansa aikana löytää hyvän ystävän, hän on saanut aarrettakin enemmän. Kirjoittaja tarvitsee tismalleen saman kehotuksen ja lupauksen. Kirjoittamisen alussa tulisi olla houkutusta lähteä hieman arveluttavallekin matkalle, päämääränä jossain vaiheessa matkaa toivottavasti löytyvä jonkinlainen aarre tai palkkio. Tulisi olla halua kertoa ja oppia jotain, löytää kumppaneita, saada viettää aikaa kiinnostavan aiheen parissa. Vasta kun nämä löytyvät, on virkamies- tai naistyön aika, voi suunnitella kuljettavaa matkaa pienin askelin.

Miten silauksen kultaruukun tai ystävyyden lumosta saisi jo kirjoittamistyön alkuun? Tähän kysymykseen ainakaan prosessimalli ei anna vastausta. Sitä voi kuitenkin lähteä kehittelemään suuntaan, joka ottaa kirjoittamisen ja syntyvän tekstin luonteen paremmin huomioon. Olen nimittänyt kehitelmää tutkivaksi kirjoittamisprosessiksi. Siinä työvaiheita on kolme: koonti, analyysi ja synteesi. Koontivaiheessa kirjoittaja kokoaa tietoa, analyysivaiheessa keskittyy yksittäisten tekstin osien valmistamiseen, esimerkiksi kirjoittaa tekstiä luku kerrallaan, ja synteesivaiheessa luo koheesion kokonaisuudelle. Toisin sanoen viimeistään synteesivaiheessa siirrytään sisällön esittämisestä ("content space") kerrontaan, tiedon tuottajaksi ja esittääksi ("rhetorical space") (Galbraith 1999, 138). Synteesille on monia ilmaisuja: tekstin rakenne, tekstin tarkoitus, juoni, punainen lanka, tekstin kaari. Mutta tässäkin mallissa kertomus eli kokonaisuus rakennetaan viimeiseksi.

\section{Opinnäyte kertomuksena}

Syksyllä 2009 aloittelin jälleen yhtä kirjoittamisen kurssia maisteriopiskelijoille ja ajattelin kokeeksi kääntää mallin toisin päin. Entä jos lähtisikin liikkeelle työn suunnittelemisen sijaan opinnäytteen kirjoittamisen ehkä palkitsevimmasta osasta, siitä että saa kertoa lukijoille, mitä onkaan tullut tutkineeksi ja oivaltaneeksi? Entä jos kiipeäisi latvasta puuhun, kurkistaisi ensin sateenkaaren päähän? Voisiko kirjoitustehtävässä näin simuloida "oikean" kirjoittamisen tuntua tavoitteesta tai tarpeesta, joka parhaimmillaan aloittaa, siivittää ja päättää kirjoittamisprosessin, siis kulkee eri tavoin jatkuvasti mukana?

Toki opinnäytteeseen sisältyy kirjoittajan suorittama tutkimustyö menetelmineen, teorioineen ja aineistoineen. Mutta viime kädessä opinnäytekin on teksti, ja sitä myös arvioidaan tekstinä monenlaisine muoto- ja tyylipiirteineen sekä sosiaalisine konventioineen. Jos kirjoittaja on päässyt synteesivaiheeseen asti, tutkimustulokset ja ilmaisulliset valinnat välittyvät tekstin sisällöllisenä ja rakenteellisena merkityksellisyytenä ne toimivat yhteistyössä viestiäkseen aiheesta valitulle lukijakunnalle kirjoittajan tarkoittamalla tavalla. 
Tieteellisen kirjoittamisen opettamisen tutkijat Barbara Kamler ja Pat Thompson (2006) muistuttavat, ettei tieteellisen tekstin lukija toivo luettavakseen vain selostusta tosiasioista. Lukija toivoo luettavakseen sitä "tarkoitusta", minkä vuoksi teksti on kirjoitettu - siis kultaruukun tai kumppanuuden silausta. Opinnäyte ei ole vain kertomus aiheesta, vaan se on myös kertomus tutkimisesta, kirjoittajan tekemästä työstä. Kamler ja Thompson (mt., 84) jäsentävät opinnäytteen rakenteen kertomukseksi tutkimuksen tekemisestä taulukon 1 osoittamalla tavalla:

\begin{tabular}{|c|c|}
\hline OPINNÄYTTEEN OSA & KERRONTA \\
\hline Johdanto & $\begin{array}{l}\text { - Tällainen on minun kokemukseni } \\
\text { Aion toteuttaa tutkimukseni näin ja } \\
\text { näistä syistä }\end{array}$ \\
\hline Kirjallisuuskatsaus & $\begin{array}{l}\text { - Näin muut ovat tutkineet aihetta ja } \\
\text { näitä asioita he ovat havainneet } \\
\text { Näin oma tutkimukseni jatkaa/täy- } \\
\text { dentää jo tehtyjä tutkimuksia }\end{array}$ \\
\hline Menetelmät & $\begin{array}{ll}\text { - } & \text { Näin muut tutkijat ovat pohtineet } \\
\text { menetelmiä / tehneet tutkimuksensa } \\
\text { - } \quad \text { Näin itse tein tutkimukseni }\end{array}$ \\
\hline Analyysi & - $\quad$ Nämä asiat löysin \\
\hline Pohdinta & $\begin{array}{l}\text { - Näin tulkitsen saamani tulokset ja } \\
\text { näin pohdin niiden merkitykselli- } \\
\text { syyttä }\end{array}$ \\
\hline Lopetus & $\begin{array}{l}\text { - Näin tein tutkimukseni, nämä asiat } \\
\text { löysin ja esimerkiksi näin voisi jatkaa } \\
\text { aiheen tutkimista ja/tai soveltaa ja } \\
\text { hyödyntää tuloksia. }\end{array}$ \\
\hline
\end{tabular}

Taulukko 1

Raportoinnin ja asioiden toteamisen ja kuvailun ohella Kamler ja Thompson toisin sanoen painottavat kirjoittajan kertovaa otetta. Samalla kun kirjoittaja kertoo aiheestaan, hän myös perustelee esityksensä lukijalle, onhan esitettyjen väitteiden perusteleminen eli argumentaatio opinnäytteen keskeisimpiä tavoitteita. Tavallaan opinnäytteessä rakentuukin kaksi kertomusta: ensinnäkin tutkimusaiheen rekonstruktio ja toiseksi esitettyjen väitteiden konstruktio ja argumentaatio, joukko kirjoittajan suorittamia valintoja, joiden tehtävänä on vaikuttaa lukijaan (Törrönen 2002). Ensimmäinen nousee tutkimuksen tuloksista, kun taas toinen on parhaimmillaan tutkimuksen tuloksena rakentunut oivallus siitä, miten juuri tämän aiheen selvittäminen kannattaa lukijalle kertoa.

Mikään ei kuitenkaan estä aloittamasta kirjoittamista kertomuksen keinoin. Oletankin, että opinnäytteen kirjoittaja voi lähteä liikkeelle kertomalla tutkimuksestaan, toisin kuin aiemmin siteeraamaani mallit, prosessikirjoittaminen ja tutkiva kirjoittamisprosessi esittävät. Nehän näkivät kerronnallisuuden joko tekstin muokkausvaiheessa 
lisättävänä metatekstinä tai synteesivaiheen koheesion luomisena. Mutta jos opinnäytteen kirjoittaja aloittaisi kertomalla, hän voisi tutkimustarinallaan motivoida itseään ja nostattaa itsessään etsimisen halun. Tutkimustarina voisi toimia myös työohjeen tavoin. Kun kirjoittaja voisi askel kerrallaan lähteä täydentämään tarinaansa ja hän voisi myös muokata ja suunnata sitä uudelleen, se voisi helpottaa pitkällistä kirjoittamisen prosessia. Oma tutkimustarina voisi auttaa kirjoittajaa selkeämmin hahmottamaan, mitä kiehtovaa kohden hän ehkä on matkalla ja miksi, mikä on juuri hänen aarteensa ja keitä hän haluaa kumppaneiksi matkalleen.

\section{Tutkimustarinat kirjoittamisen aloittamisen apuvälineenä}

Päätin siis kirjoituttaa syksyn 2009 tieteellisen kirjoittamisen kurssilaisilla oman tutkimustarinan kurssin alkuvaiheessa, tilanteessa, jossa olimme ehtineet käsitellä vasta kaksi asiaa: hieman opinnäytteen merkitystä ja funktiota sekä hieman työskentelyprosessin eri vaiheita. Lisäksi opiskelijat olivat laatineet aiheestaan ideapaperin ja niitä oli kommentoitu pienissä ryhmissä. Kirjoittamisen mallien näkökulmasta olimme alkuvaiheessa, mutta teimme kurittoman hypyn kohti latvaa.

Johdatukseksi tutkimustarinoihin luimme yhdessä Jukka Törrösen artikkelin "Tieteellisen tekstin rakenne" (2002). Siinä Törrönen esittelee seuraavat tutkimusraporteissa hyödynnetyt tarinamallit:

mysteeri/dekkarikertomus

analyyttinen tarina

monen tarinan malli

hypoteesitarina

Täydensin seuraavilla tarinatyypeillä Törrösen esittämää listaa:

esseistinen kertomus tai matkakertomus

kasvu- tai kehityskertomus

Tehtävänantoni oli varsin yksinkertainen: opiskelijoiden tuli miettiä noin kolmen hengen ryhmissä, millaisen tutkimustarinan itse kukin heistä voisi aiheestaan kirjoittaa. Painotin, että käytännössä tarinatyypit limittyvät; yhdessä tutkimuksessa voi esiintyä rinnan useitakin tarinatyyppejä, mutta yleensä yksi tarina on muita korosteisempi. Keskustelun jälkeen jokainen opiskelija kirjoitti kotona oman tutkimustarinansa ja palautti sen seuraavaan tapaamiseen mennessä. 13 opiskelijan tutkimustarinoiden suunnitelmissa mainittiin seuraavat mahdolliset tutkimustarinoiden mallit:

seikkailu-, dekkari- tai mysteeritarina 7 kertaa

matkatarina 3 kertaa

kasvutarina 3 kertaa

kaksi tai useampi tarinaa 3 kertaa

analyyttinen tarina 3 kertaa

dialogi, "tulkitseva realismi" 2 kertaa

hypoteesitarina 1 kertaa 
Lähes jokainen kirjoittaja mainitsi pohtivansa kahta mahdollista tarinamallia ja/ tai niiden yhdistämistä. Vain kolme kirjoittajaa oli jo valinnut yhden tarinamallin. Jokainen näistä kolmesta oli päätynyt yleisimpään kategoriaan eli seikkailu-, mysteeritai dekkaritarinaan. Lainaan seuraavassa kaksi tekstiä kokonaisuudessaan kirjoittajien myötämielisellä luvalla.

\section{Esimerkki 1:}

\section{Uniikeista teoksista painetuiksi kirjoiksi: tutkimus taiteilijakirjojen lajityypeistä ja motiiveista}

Tutkimuskysymys: Miksi taiteilija valitsee taiteilijakirjan mediakseen? Makrotason kertomus on mysteeritarina.

Ensimmäisessä osassa esitellään mysteeri eli määritetään tutkimuksen tutkimuskysymys, osakysymykset ja termistö. Sen jälkeen tarinan etsivä, tutkija, selvittää tapauksen taustat, tutkii taiteilijakirjojen historian, ja kerää johtolankoja siitä, missä taiteilijakirjoja syntyy, millä tavoin ja miksi. Etsivä jatkaa tutkimustaan haastattelemalla mahdollisia taiteilijoita, kustantajia ja taiteilijakirjojen lukijoita, jotka saattavat tietää lisää asiasta. Etsivällä on myös oma subjektiivinen käsitys aiheesta. Tämä tulee esiin sivujuonessa, jossa hän työstää omaa taiteilijakirjaansa omista lähtökohdistaan. Johtolankojen, haastattelun ja oman kokemuksen avulla etsivä lopulta vastaa tutkimuskysymyksiin ja (toivottavasti) ratkaisee mysteerin.

\section{Esimerkki 2:}

Lopputyön "Poissaolo kuvassa" kirjallinen osuus tuntuisi luontevasti taipuvan dekkarimuotoiseksi tarinaksi, jossa kuljeskellaan johtolankoja etsiskellen. Johtolankoja tai jälkiä ovat kuvista löytyvät vihjeet siitä, että niistä on juuri poistuttu (kuva-alan ulkopuolelle).

Kirjallisessa osuudessa olisi alusta pitäen selvää, että tarinan lopputulema ei ole mysteerin ratkaisu, vaan merkittäviä ovat johtolangat ja niiden luonne sekä tutkimusmatka itsessään.

Teksti voisi alkaa siten, että johtolangat kerättäisiin eri teoksista ja esiteltäisiin yksityiskohtaisesti ja "arkistoitaisiin". Sen jälkeen niitä olisi mahdollista ottaa tarkastelun alle, joko yksittäisinä tai useita kerrallaan, vertaillen jotakin tiettyä ominaisuutta tai keskittyen tarkasti vain yhteen ja ainokaiseen. Lukija olisi jo johtolankojen vanha tuttu. Niistä paljastettaisiin hänelle pikkuhiljaa uusia ominaisuuksia, niiden luonnetta valotettaisiin eri kulmista.

Olisi toki kiinnostavaa havaita, jos näille toisistaan kovastikin poikkeaville vihjeille löytyisikin joku yhteinen nimittäjä. Tämä ei ole vielä selvillä...

Ei tietystikään ole suuri yllätys, että dekkarikertomuksen malli tuntui ainakin näistä kirjoittajista helpoimmin sovellettavalta. Onhan dekkareissa kysymyksessä yleensä arvoituksen ratkaiseminen tiedonhankinnan keinoin. Opiskelijoiden kirjoittamissa teksteissäkin dekkaritarinan antamaa mallia oli sovellettu eniten, mistä päättelin sen hyödyntämisen suhteellisen helpoksi tutkimustyön alussa. Se on juonellinen, tarjoaa 
sopivat roolit ("etsivä", "arvoitus") ja on lajityyppinä populaari.

Ainakin tämän kurssin opiskelijoista tutkimustarinan kirjoittaminen tuntui mielekkäältä. Ennen kaikkea tutkimustarinan kirjoittaminen vaikutti tuovan esiin tutkimuksen suorittajan aktiivisen otteen. Opinnäytteen idea selkiytyy, kun sille löytyy konkreettinen arvoituksen ratkaisemisen tai esimerkiksi tutkijan suorittaman matkan metafora. Tämä puolestaan vastaa monen arkikokemusta siitä, mikä kirjoittamisessa on kiehtovaa, nimittäin uuden kokonaisuuden rakentaminen ja oivallusten jäsentyminen sekä niiden myötä jonkin uuden avautuminen. Samaan viittaa käyttöteoriani kultaruukusta ja matkalta löytyneestä kumppanista. Kumppanit voivat olla monenlaisia: reaalimaailman lukijoita, tärkeitä tekstejä, virittäviä teorioita tai taideteoksia - toiset puhuvat myös muusista, jotka innoittavat kirjoittajaa kirjoittamaan yhä enemmän ja yhä paremmin.

\section{Mikä tarinoissa vetoaa?}

Ihminen on tarinoita kertova eläin, homo narrans, ja tarinoissa on jotain yleisinhimillisen kiehtovaa.

Arkiajattelussa tieteellinen esitystapa ja tarinat vain on totuttu erottamaan tiukasti toisiinsa kahteen eri kategoriaan, faktaan ja fiktioon. Mutta Kamlerin ja Thompsonin tapa lähestyä tieteellistä tekstiä tarinana auttaa ymmärtämään, että tarinat eivät ole vain sepitettä, vaan niiden avulla ihmismielet pystyvät ymmärtämään kokonaisuuksia helpommin ja kenties nautittavammin. Samalla on tietysti muistettava kääntöpuoli: tarinamaisuus voi myös "vietellä", johtaa harhaan ja nousta korosteiseksi, jolloin tutkimustekstin pääasiallinen tarkoitus, selostus tiedon tuottamisesta, voi kärsiä (White 1980, 8).

Kamlerin ja Thompsonin ajatuksissa kajastaa niin sanottu narratiivinen käänne, suuntaus, joka sai jalansijaa ihmistieteissä 1980-luvulta alkaen. Painotettiin, että kertomuksella ja kerronnalla on suuri merkitys ihmisen toiminnassa ja kulttuurissa, ei vain perinteisessä mielessä kertomuksiksi luokiteltavissa teksteissä. Narratiivista otetta on sittemmin sovellettu monilla tutkimuksen alueilla sosiaali- ja kasvatustieteistä psykologiaan ja historiantutkimukseen. Yhteistä näille on ollut näkemys, että kertomus on ihmismielelle tyypillinen tapa tehdä maailma ymmärrettäväksi ja jakaa ymmärrystä maailmasta. Tarinoita kannattaakin tässä yhteydessä lähestyä ei niinkään niiden muodon näkökulmasta, vaan niiden funktion, toiminnan tasolta.

Toiminnan teorian suomalaisen kehittäjän Yrjö Engeströmin mukaan ihminen on yhdessä toisten kanssa toimiva olento, joka käyttää kulttuurin tarjoamia välineitä omaan toimintaansa (Engeström 2004, 9). Teorian varhaiset oppi-isät, venäläiset psykologit Lev Vygotski, A. N. Leontjev ja A. R. Lurija oivalsivat jo 1920-luvulla, että ihmistä ei voi ymmärtää erillisenä olentona eikä abstraktien, toisistaan erillisten ominaisuuksien 
kautta. Sen sijaan tulee katsoa, miten hän toimii.

Toiminnalla on aina kohde. Se on "yhteisöllisesti merkitykselliseen tarkoitukseen suuntautuvaa”, ei sattumanvaraista, hetkellistä ja impulssien aiheuttamaa käyttäytymistä. Se on myös välittynyttä, mikä tarkoittaa sitä, että tarkoituksen saavuttamiseen käytetään joitain kulttuurissa kehittyneitä välineitä. Välineet voivat olla joko aineellisia työkaluja tai sopimuksenkaltaisia käsitteitä tai merkkejä, joiden käyttöä säätelevät yhteisön jakamat säännöt. (mt., 9.)

Tarinoita voi pitää kirjoittajan aineellisina työkaluina silloin, kun hän hyödyntää kirjoittamisessaan esimerkiksi aiempien tekstien tarjoamia malleja. Tarinallisuutta voi pitää myös sopimuksenkaltaisena käsityksenä siitä, millaiset kielelliset esitykset ovat ymmärrettäviä ja usein kiehtovampia kuin toiset. Kun kirjoittaja hyödyntää kirjoittamisessaan tarinoita, hän siis nojaa kulttuurissa olevaan ymmärrykseen siinä toivottavista ja arvostetuista esittämisen tavoista.

\section{Kaaret ja kultaruukut, virrat ja kristallit}

Pelkkä hyvää tarkoittava toiminta ei riitä, pitää tulla myös tulosta. Pelkkä tarinakaan ei riitä, tarvitaan sisältöä. Lastenlaulussa luvattiin ruukullinen kultaa, mutta löytääkö kirjoittaja kultaruukkunsa valmiina? Tuskin. Kirjoittaja valmistaa itse oman aarteensa kirjoittaessaan.

Sosiologi Laurel Richardson on tarkastellut kirjoittamista tutkimusmenetelmänä. Hän käyttää kirjoittamisesta kristallin ja kristallisoitumisen metaforaa. (Richardson \& St. Pierre 2005 , 963.) Metafora sai alkunsa Richardsonin tympäännyttyä luonnontieteiden perua oleviin kaksiulotteisiin ja stabiileihin tiedon esittämisen malleihin. Niissä ei tavoitettu kielen ja ihmismielen mahdollisuuksia luoda dynaamisesti jotain uutta (mt., 960). Kuitenkin kirjoittaminen on tiedon tuottamista, ja valmis teksti tutkimuksen tulos.

Richardsonin esittämää metaforaa voi purkaa pohtimalla kristallisoitumiseen liittyvää metamorfoosia. Kristalli syntyy tiettyjen (kielen) ainesten kokoonpanosta, mutta samalla muuttumalla ajan saatossa toiseksi, tiiviiksi aineeksi. Tekstin kiteytyminen on lukuisten valintojen tulosta. Toisaalta tarvitaan aines ja oivallukset, toisaalta niiden työstyminen, kriittinen tarkastelu, valikoiminen ja editointi. Parhaimmillaan aine tiivistyy ja muuttuu monimuotoiseksi. Kristallin muoto ja särmät mahdollistavat erilaisia näkökulmia, mutta kokonaisuus on kuitenkin hallittu ja perusteltu. (mt., 963.)

Kristallin metafora paitsi painottaa prosessia, tuo esille ymmärryksen moniulotteisuuden ja osallisuuden. Särmiä on monta, mutta kaikkea ei koskaan näe, ei ainakaan yhdellä kertaa. Paradoksaalisesti juuri tiedon osittaisuus mahdollistaa sen, että tiedämme enemmän ja pohdimme tietämäämme. Osittainen tieto synnyttää tiedon halun; tiedämme että jotain on vielä tietämättä. Vaikka ihastelisimme onnistunutta lopputu- 
losta, tiedämme, ettei yksikään teos voi kertoa koko totuutta. (mt., 963.)

Kirjoittamiseen vaikuttaa myös kirjoittajan paikka ja sijainti, joita tulee kunnioittaa (mt., 965). Ne ovat tekstille sekä mahdollisuus että uhka. Kirjoittaja on aina epävarmuuden tilassa. Hänellä ei ole vertailukohtana aiempaa ohjaavaa mallia, mihin hän voisi palata ja minkä keinoja vasten tarkistaa tekstinsä "turvallisuusasteen". Turvallisuusasteella tarkoitan sitä, ettei teksti poikkea aikaisemmasta ainakaan hälyttävässä määrin ja että se todella on tarkoituksenmukainen tavoitteessaan ja yhteisössään. Kiteytymisen metaforan mukaan sekä teksti että kirjoittaja ovat tulemisen tilassa, ja määränpää on aina osittain tuntematon. Samalla kun kirjoittaja on "vapaampi” ilmaisemaan, ovat riskit ja vastuu esityksestä suurempia.

\section{Entä ne kumppanit?}

Lastenlaulun romantisoivalle kuvaukselle ystävästä aarrettakin arvokkaampana löytönä voi tietysti hymähtää. Mutta ainakin kirjoittamisessa se pitää paikkansa. Kirjoittaminen edellyttää käsitteellisiä työkaluja, kulttuurisia merkkejä ja niiden kanssa koettua kumppanuutta. Siihen punoutuu ympäristön ääniä, kuvia ja kaikuja. Jostain aineen takertumisesta toiseen, tihentymisen hetkestä kristallisoituminen aina alkaa.

Kumppanin ei tarvitse eikä hän aina voikaan olla fyysinen henkilö. Opinnäytteen kirjoittajan kumppaneita ovat aineisto, tutkimuskirjallisuus ja tutkimusyhteisö sekä siinä tapahtuva vuorovaikutus sekä kaikki muu tutkimustyöhön virittävä. Vaikka kirjoittaja hautautuisikin aika ajoin kammioonsa saadakseen työrauhan, sisäinen kirjoittamisrauha ja motivaatio kumpuavat siitä tiedosta, että tekstillä on yhteisö, tarkoitus ja jokin kohde.

Tätä tekstiä ensi kerran kirjoittaessani kumppani löytyi yllättävältä taholta. Valmistelin luentoa ja etsin kuvitusta luentokalvoihini. Googlaamastani kuvasaalista eräs teoskuva, hollantilaisen Jan Vermeerin maalaus kirjettä kirjoittavasta naisesta, jäi jostain syystä mieleeni. Noin vuonna 1670 valmistunut maalaus on suomenkieliseltä nimeltään Kirjettä kirjoittava nainen ja kamarineiti. Muistan ensin hieman sadatelleeni mokomaa kuvaa. Vermeerin kirjoittavan naisen interiöörinä on putipuhdas huone. Minusta se antoi harhaanjohtavan idyllisen kuvan kirjoittamisesta, joka pääasiassa on täyttä kaaosta. Lisäksi olin vastikään lukenut jostain Potter-äiti J.K.Rowlingin ajatuksen, että nainen ehtii tekemään seuraavista asioista kaksi: kirjoittamaan, hoitamaan perheensä ja siivoamaan. Kirjettä kirjoittava nainen palvelijaneito taustallaan ei oikein sopinut tähän ajatukseen.

Vähitellen aloin löytää maalauksesta tasoja, muutakin kuin vain sananmukaisesti puhdasta pintaa. Naisella on kädessään ihastuttava sulkakynä, edessään työpöytä ja paperia. Ne ovat näkyvillä maalauksen pinnassa, tunnistettavina kuva-aiheina. Mutta poissa on se, jolle kirje osoitetaan. 
Vai onko hän poissa? Vermeerin taiturimainen valon ja varjon käyttö luo kuvaa seesteisestä ja yksityisestä hetkestä. Samalla maalauksen kompositiota tarkasteleva voi huomata, että maalaukseen aukeaa tila, jossa naisen alaspäin, paperiin kiinnittynyt katse piirtääkin suunnan ulkomaailmaan, kuten Mark Harden on todennut (2009). Ikkunasta tulvii valoa ja verhot näyttävät heiluvan. Ulkona, rauhaisan tilan ulkopuolella, on jokin maailma, joka on viehättävästi sekä huoneen ulkopuolella että siihen kytköksissä. Sinne nainen osoittaa sanansa. Siellä on joku, jolle nainen kirjoittaa.

Monet kirjoittajat rakentavat ikään kuin puhetilanteen päähänsä tai huoneen sisään saadakseen tekstiinsä vuorovaikutuksen tunnun. Maalauksen näennäisen hiljainen tila voikin olla täynnä ääniä. Tietysti työhönsä syventynyt kirjoittaja saattaa tarvita hiljaisuutta ja rauhaa, mutta samalla toiset ihmiset, lukijat, ovat tärkeintä mitä hänellä on. Ilman toista, sitä jolle tai josta kertoa, kirjoittaja ei ehkä saa tekstiään inhimillisen koskettavaan muotoon. Ilman lukijoita hänen tekstinsä eivät syty ja jää elämään. Ja usein vasta toiselle kertoessaan itsekin pääsee jyvälle siitä, mitä oikeastaan haluaakaan sanoa.

Vermeer tekee sen, mihin moni kirjoittaja pyrkii ja harvemmat pystyvät. Hänen teoksensa ovat pinnalta katsoen realistisia. Hän kuvasi usein ihmisiä, jotka olivat pysähtyneet hiljaiseen tilanteeseen tai joilla oli jokin melko yksinkertaiselta vaikuttava tehtävä työn alla. Usein hänen henkilönsä kaatavat vettä tai maitoa, lukevat tai kirjoittavat kirjeitä tai valmistavat koruja. Maalaukset kutsuvat katsomaan tavallista elämää ja pysähtymään sen hetkien äärelle, mutta ilmaisullaan Vermeer muuttaa yksityisen ja pienen yleispäteväksi ja suureksi. Realismi syvenee universaaliksi ja yksityiset interiöörit saavat voimaa ja kantavuutta. Valot ja varjot luovat jopa metafyysisen tunnelman kuviin. Lisäksi hän käyttää taitavasti kompositiota. Hän asettelee kuvapinnan elementit tavalla, joka kertoo, että näemme tärkeästä vain osan (mt.). Aivan kuten jokaisen tekstin kirjoittaja kirjoittaa vain osan, lukija pystyy lukemaan vain osan. Loput lukija täydentää mielessään.

\section{Lopetus}

Kaikesta kirjoittamisesta jää osittaisen tuntu. Niin tutkimustarinoistakin, samoin tästä esseestä. Valintoja joutuu tekemään. Moni tärkeä henkilö ja episodi jää kertomuksen ulkopuolelle.

Rajaaminen on ehdottoman tärkeää. On kysymys viime kädessä kompositiosta, kokonaisuuden luomisen periaatteesta ja samasta periaatteesta kiinni pitämisestä. Näin erityisesti hyvässä, läpinäkyvässä, rajansa tuntevassa kirjoittamisessa.

Tässä esseessä olen yrittänyt hahmotella yhden kirjoittamisen apukeinon eli toiminnanteorialaisittain työkalun merkitystä. Kirjoittajan suhde työkaluihinsa ja kirjoittaminen toimintana on toistaiseksi varsin vähän tutkittu alue, jos vaikkapa vertaa prosessikirjoittamisen käytäntöihin tai muihin kirjoittamisen opetuksen menetelmiin, 
esimerkiksi genrepedagogiikkaan. Havaitsin, että tutkimustarina, jota voi lähestyä yhtenä kulttuurisena työkaluna, voidaan laatia vasta ideavaiheella olevasta tutkimuksesta. Ei tarvitse odottaa tekstin muokkaamiseen.

Oletan opetuskokeiluni perusteella myös, että tutkimustarinan kirjoittaminen voi motivoida kirjoittajaa pitkäjänteiseen työskentelyyn, sillä se auttaa hahmottamaan kirjoittamisen tuloksena syntyvää, lukijalle kommunikoivaa valmista tekstiä ja sitä, millainen kirjoittaja haluaa sen mahdollisesti olevan. Tutkimustarina voi myös auttaa määrittelemään niitä tutkimuksen osia ja välivaiheita (henkilöitä, tapahtumapaikkoja, motiiveita, juonenkulkuja), joita kirjoittaja voi tarvita varsinaisen tutkimuksensa kertomiseksi. Monet kirjoittajat ovat aina osanneet laatia tutkimuksistaan hyviä tarinoita, me vain lukijoina ja kirjoittamisen ohjaajina emme ole vielä riittävästi valveutuneet ottamaan näitä asioita opetuksessa huomioon. Ja vaikka jokainen kaari ei johtaisikaan suoranaisesti kultakimpaleeseen, hyvän oppimisen kokemuksen etsimisestä voi silti saada. Tai teksti voi valmistua ja tarina päättyä, mutta siten, että teemat ja kysymykset jäävät ilman lopullista ratkaisua, ikään kuin ilmaan, odottamaan seuraavia mahdollisia kertomuksia.

\section{Lähteet}

ENGESTRÖM, YRJÖ 2004: Ekspansiivinen oppiminen ja yhteiskehittely työssä. Tampere: Vastapaino.

Galbraith, David i 999: Writing as a Knowledge-Constituting Process. Knowing What to Write: Conceptual Processes in Text Production. Eds. Mark Torrance \& David Galbraith. Amsterdam: Amsterdam University Press.

HARDEN, MARK 2009: (Ei otsikkoa). <http://www.artchive.com/artchive/V/vermeer/ lady_writing.jpg.html> (23.9.2009)

IVANIC, ROZ 2004: Discourses of writing and learning to write. Language and Education $3 / 18,220-245$.

Kamler, Barbara \& thompson, Pat 2006: Helping Doctoral Students Write. Pedagogies for Supervision. London \& New York: Routledge.

LINNAKYlä, PIRJO, MATTINEN, EIJA \& OLKINUORA, ASTA I992: Prosessikirjoittamisen opas. 1.-3. painos. Helsinki: Otava.

Richardson, LAURel \& ST. PIERRE, Elisabeth 2005: Writing a Method of Inquiry. Handbook of Qualitative Research Third Edition. Eds. Norman K. Denzin \& Yvonna S. Lincoln. Thousand Oaks: Sage Publications.

TÖRRÖNEN, JUKKA 2002: Tieteellisen tekstin rakenne. Tieteellinen kirjoittaminen. Toim. Merja Kinnunen \& Olli Löytty. Tampere: Vastapaino.

White, HAYDen I980: The Value of Narrativity in the Representation of Reality. Critical Inquiry 1/7, 5-27. 